\title{
zons

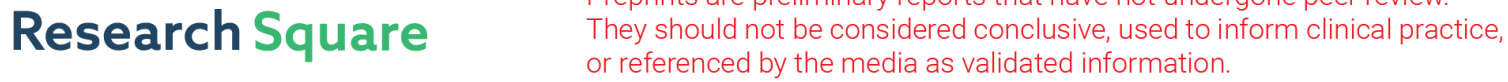 \\ Lack of Benefit in COVID-19 Patients Treated with Hydroxychloroquine or Chloroquine: A Systematic Review and Meta-Analysis
}

\section{Liang Chen}

Department of Epidemiology, School of Public Health, Fudan University

\section{Shuoyan An}

Department of Cardiology, China-Japan Friendship Hospital, Beijing, China

\section{Guangyu Yao}

Department of Thoracic Surgery, Zhongshan Hospital, Shanghai Medical College, Fudan University,

Shanghai

\section{Jiasheng Xiong}

Department of Epidemiology, School of Public Health, Fudan University

\section{Haiyan Xiong}

Department of Epidemiology, School of Public Health, Fudan University

\section{Ping Zhao}

Department of Epidemiology, School of Public Health, Fudan University

\section{Lufang Jiang}

Department of Epidemiology, School of Public Health, Fudan University

\section{Wei Hua}

Fuwai Hospital, National Center for Cardiovascular Diseases, Chinese Academy of Medical Sciences and Peking Union Medical College, Beijing

Chenglong Xiong ( $\nabla$ xiongchenglong@fudan.edu.cn )

School of Public Health

\section{Firat Duru}

University Heart Center, Zurich, Switzerland

\section{Qingwu Jiang}

Department of Epidemiology, School of Public Health, Fudan University

\section{Scoping Review}

Keywords: COVID-19, hydroxychloroquine, chloroquine, viral clearance, outcome, meta-analysis

Posted Date: June 30th, 2020

DOl: https://doi.org/10.21203/rs.3.rs-33047/v2 
License: (c) (i) This work is licensed under a Creative Commons Attribution 4.0 International License. Read Full License 


\section{Abstract}

Background: Hydroxychloroquine (HCQ) and chloroquine (CQ) have been widely used for the treatment of the coronavirus disease 2019 (COVID-19), despite limited clinical evidence and controversial early reports. The aim of this report was to provide a systematic review of the literature and meta-analysis on the use of HCQ/CQ with respect to safety and clinical efficacy of these medications.

Methods: We performed a systematic search of the medical databases and included studies if they focused on patients with COVID-19 who received HCQ or CQ alone, or in combination with other treatments, and were compared with a control group. We analyzed two important clinical objectives; viral clearance rate by reverse transcription-polymerase chain reaction (RT-PCR) negativity and all-cause mortality.

Results: A total of 14 studies were included in the quantitative synthesis. The use of HCQ/CQ was associated with higher viral clearance rate compared with control group (OR: 3.12, 95\% Cl: 2.17-4.49 $\mathrm{p}<0.0001)$. In the sensitivity analysis, the effect on viral clearance disappeared (OR 1.44, 95\% Cl: $0.87-$ $2.37, p=0.155)$. The use of HCQ/CQ was associated with a higher risk of mortality (OR $1.26,95 \% \mathrm{Cl}: 1.05-$ $1.51, p<0.0001)$. Due to huge heterogeneity between the studies $(R=86 \%, p<0.01)$, we performed a meta regression analysis. Both treatment within 24 hours $(p=0.047)$ and comorbidities [hypertension $(p=0.025)$, diabetes $(p=0.049)$ and chronic lung disease $(p=0.0064)]$ contributed to the heterogeneity. HCQ/CQ daily dose $(p=0.61)$ and age $(p=0.62)$ had no impact on effect size. Higher rate of comorbidities led to a higher risk of mortality by using HCQ/CQ. Overall, the use of HCQ/CQ resulted in longer QTc intervals.

Conclusions: Our meta-analysis did not reveal a clinical benefit of HCQ/CQ on in-hospital outcomes for patients with COVID-19. The use of HCQ/CQ did not result in rapid viral clearance on RT-PCR. Moreover, our results showed that higher rate of comorbidities led to a higher risk of mortality by using HCQ/CQ.

\section{Introduction}

The pandemic of coronavirus disease 2019 (COVID-19), caused by severe acute respiratory syndrome coronavirus 2 (SARS-CoV-2), has resulted in considerable morbidity and mortality in millions of infected patients [1, 2]. The overall mortality of the COVID-19 was determined to be $2.3 \%$ among general laboratory-confirmed cases [3], but the fatality rate was more than $10 \%$ among hospitalized patients, and even reached to $40 \%$ among critically ill cases [4]. There is yet not a specific therapy for COVID-19, but several repurposed drugs have been widely used including hydroxychloroquine (HCQ) and chloroquine (CQ). Both of these drugs have been commonly used to treat malaria, systemic lupus erythematosus and rheumatoid arthritis before, and have also been demonstrated to inhibit SARS-CoV-2 effectively in vitro [5, $6]$.

Early studies suggested a potential clinical benefit by using HCQ/CQ but there were also contradictory reports. An open label non-randomized clinical trial on 36 patients revealed more rapid viral clearance by HCQ administration [7]. In contrast, a simultaneously reported small size random control trial (RCT) on 30 
patients from China did not show an accelerated viral clearance by HCQ [8]. Another study on 62 patients showed that HCQ significantly improved the recovery of pneumonia assessed by chest CT scan, but the endpoints of viral clearance and mortality were not evaluated in this study [9]. Nevertheless, despite limited medical evidence, the Food and Drug Administration in the United States urgently authorized the use of HCQ/CQ in the treatment of COVID-19 infection in March 2020, followed by widespread use of these medications around the world, which also raised some concern [10]. More recently, several other HCQ/CQ studies have been reported, but the clinical efficacy of these drugs has been controversial because of the limited sample size and mostly observational nature of these studies. Other concerns with the use of HCQ/CQ include prolongation of the QTc interval, which may subsequently cause lifethreatening ventricular arrhythmias [11]. For these reasons, several national guidelines recommend the use of these two medications only in the hospital setting $[12,13]$.

The aim of this report was to provide a systematic review of the medical literature and meta-analysis on the use of HCQ/CQ with respect to safety and clinical efficacy of these medications in the treatment of patients with COVID-19. We analyzed two important clinical objectives; viral clearance rate by reverse transcription-polymerase chain reaction (RT-PCR) negativity and all-cause mortality for meta-analysis. In addition, we studied the adverse events and electrophysiologic alterations with the use of these medications.

\section{Methods}

We performed this study in accordance to the Preferred Reporting Items for Systematic review and MetaAnalysis (PRISMA) guidelines.

\section{Search strategy}

We performed a systematic search of the English databases (PubMed, Embase, Web of Science, the medRxiv) and the Chinese databases (China National Knowledge Infrastructure and WanFang) until May 15,2020 . Besides, we performed gray literature search using online search engines and hand search through the table of contents of key journals. We used the following keywords in our search: "COVID-19", "SARS-CoV-2", "2019 novel coronavirus", "2019-nCoV", "coronavirus disease 2019", "coronavirus disease19", and "2019-nCoV", "hydroxychloroquine", "chloroquine" in the title or abstract fields. Boolean operators (AND, OR, NOT) were used as appropriate to identify relevant literature. No filters were set for the search process.

\section{Criteria of inclusion and exclusion}

Studies were included if they focused on patients who received HCQ or CQ alone, or in combination with other treatments for COVID-19 infection and were compared with a control group. Both RCTs and observational studies were included. One of the following outcomes should be described for inclusion: (i) mortality, (ii) clinical progress, (iii) results of the RT-PCR test after the commencement of treatment, (iv) 
adverse clinical events. Only studies in English and Chinese were included. Case reports, non-human studies and studies without adequate information were excluded.

\section{Data extraction and quality assessment}

Data on study design, location of the study, the number of participants in each group and the dose of HCQ/CQ were collected independently by two authors (HX, SA). The outcomes included mortality, clinical deterioration, viral clearance and adverse events. For the adverse events, we only focused on QTC prolongation and ventricular arrhythmias. The Cochrane risk of bias tool was used to evaluate RCTs. The ROBINS-I tool was used to assess the risk of bias in observational studies. Disagreement between investigators was resolved through discussion with the third investigator (GY).

\section{Data synthesis and meta-analysis}

The outcomes studied were dichotomous; point estimates are expressed as odds ratio (OR) with the $95 \%$ confidence interval $(\mathrm{Cl})$. The inherent heterogeneity among studies was assessed by two statistical methods, Cochrane $Q$ and $R$, in which $R<50 \%$ indicated moderate heterogeneity, whereas $R>50 \%$ was considered great heterogeneity. Sensitivity analysis was performed by sequential omission of each study to assess the influence of single data on the pooled OR. Publication bias were evaluated by Egger's test. A p-value $<0.05$ was considered to be statistically significant.

\section{Meta-regression analysis}

Meta-regression analysis was performed to explore the potential moderators that may affect the outcome. Following variables were analyzed in meta-regression analysis: region, mean age, sample size, daily dose, disease severity and comorbidities (chronic lung disease, hypertension and diabetes). The regression coefficients (minimum estimate), 95\% Cls, 2-sided p values, and Tau square were reported. All analyses were performed using R 4.0 .0 with meta package.

\section{Results}

\section{Literatures search and flow diagram}

We identified 840 publications through electronic medical database searching. Another 5 articles were obtained through hand searching. 306 duplicate articles were excluded. In the remaining 539 articles, 495 were excluded after screening title and abstract. After evaluating the full text of 44 publications, 21 were excluded. A total of 23 studies were included in the qualitative synthesis, of which 9 articles only reported safety issues were excluded in the meta-analysis. The numbers identified at each stage from database searching to quantitative analyses and the reasons for excluding studies are shown in Figure 1.

\section{Study characteristics}


A total of 14 studies were included in the quantitative synthesis. Characteristics of included studies were shown in Table 1. In the 14 studies, 9 were retrospective studies, 1 prospective observational study, 1 nonRCT and 3 RCTs. For all studies, 9 studies discussed mortality between HCQ/CQ and control groups, and 7 studies reported the effect of HCQ/CQ on viral clearance.

\section{The efficacy of HCQ/CQ on viral clearance}

Viral clearance was assessed by RT-PCR in 7 studies at time point ranging from the sixth day to the twenty-eighth day. As shown in Figure 2, this pooled analysis consisted of 366 patients in the HCQ/CQ group and 565 patients in the control group. The use of HCQ/CQ was associated with higher viral clearance rate compared with control group (OR: 3.12, 95\% Cl: 2.17-4.49 p<0.0001). In the sensitivity analysis shown in Figure $3 A$, by omitting the study by Huang MX et al [14], the effect on viral clearance disappeared (OR 1.44, 95\% Cl: 0.87-2.37, $\mathrm{p}=0.155)$. By omitting any of the other studies, HCQ/CQ still showed advantage in viral clearance. This result suggested study by Huang MX [14] was dominant in the pooled OR. No significant publication bias was observed after adjustment $(p<0.0001$, Figure $3 B$ ).

Due to the huge heterogeneity between different studies $(R=80 \%, p<0.01)$, we performed a meta regression analysis. Region $(p=0.25)$, study type $(p=0.44)$, disease severity $(p=0.83)$, age $(p=0.65)$, HCQ/CQ dose daily $(p=0.74)$ and diabetes $(p=0.60)$ had no impact on effect size, whereas patients with hypertension showed a trend towards lower viral clearance rate $(p=0.14)$ (Figure 4).

\section{The efficacy of HCQ/CQ on mortality}

Mortality data were available in 9 studies. In the study by Geleris $J$ [15] and Rosenberg E [16], patients in the HCQ/CQ group were more severe than in the control group at baseline, so the authors performed statistical adjudgments to reduce confounding. In our meta-analysis, only figures after adjudgments were included. As shown in Figure 5, 1006 patients received HCQ/CQ and 432 patients were included in the pooled analysis. The use of HCQ/CQ was associated with a higher risk of mortality (OR $1.26,95 \% \mathrm{Cl}$ : 1.05-1.51, p 0 0.001). In the sensitivity analysis (Figure 6A), by omitting the studies by Rosenberg E [16], Geleris J [15] and Magagnoli [17], mortality was no longer found to be significant between the HCQ/CQ and control groups. Publication bias before and after adjustment are shown in Figure $6 B$ and Figure $6 C$, and no significant publication bias was observed. Due to huge heterogeneity between these 9 studies $(R$ $=86 \%, p<0.01) \llbracket$ we performed a meta regression analysis. Both treatment within 24 hours $(p=0.0468)$ and comorbidities [hypertension $(p=0.025)$, diabetes $(p=0.049)$ and chronic lung disease $(p=0.0064)$ ] contributed to the heterogeneity. HCQ/CQ daily dose $(p=0.61)$ and age $(p=0.62)$ had no impact on clinical efficacy. Higher rate of comorbidities led to a higher risk of mortality by using HCQ/CQ (Figure 7).

\section{The impact of HCQ/CQ on QTc prolongation and arrhythmic events}

Adverse arrhythmic events were reported in 11 studies (Table 2). The incidence of QTc prolongation ranged from $9.0 \%$ to $35.0 \%$. The incidence of reported ventricular arrhythmias was lower with a range from $0 \%$ to $9.1 \%$. In 8 studies, only adverse arrhythmic events in the HCQ/CQ group were described. The 
other 3 studies compared adverse arrhythmic events between the HCQ/CQ and control groups. Overall, the use of HCQ/CQ resulted in longer QTc intervals. In the study by Borba MGS [18], high dose (600 mg twice daily) HCQ caused more QTc prolongation and ventricular arrhythmias compared to low dose (450 mg twice on Day 1 and 450 mg once on Day 2-5).

\section{Discussion}

This systemic review of medical literature and meta-analysis in patients with COVID-19 did not reveal any clinic benefit of using HCQ/CQ, even if these medications were initiated early after diagnosis. Despite large heterogeneity of the individual publications, our results suggested that the use of HCQ/CQ was associated with an increased risk of in-hospital mortality in these patients. Moreover, we showed no consistent rapid viral clearance of SARS-CoV-2 by using HCQ/CQ. The heterogeneity of the drug efficacy on mortality might be attributed to the comorbidities of enrolled subjects, such as hypertension, diabetes and chronic lung disease.

In theory, HCQ and CQ may be ideal drugs to treat SARS-CoV-2 infection as they can inhibit the virus via their antiviral effects and help mediate the cytokine storm via immunomodulation. HCQ was found to be more potent than CQ to inhibit SARS-CoV-2 in vitro [6], and exerted less side-effects in the daily clinical practice for the treatment of systemic lupus erythematosus and rheumatoid arthritis. Although the antiviral effects of HCQ/CQ on SARS-CoV-2 were confirmed by several independent in vitro studies, their clinical efficacy on COVID-19 was controversial in clinical studies. Early investigations and clinical trials reported different outcomes of HCQ/CQ treatment on clinical recovery, virus-negative conversion, symptomatic progression and death. In this study, we opted to study viral clearance rate by RT-PCR and all-cause in-hospital mortality - two clinically relevant objectives - in our meta-analysis to evaluate the clinical efficacy of HCQ/CQ in patients with COVID-19.

The earliest reported study on the use of HCQ in COVID-19 was from Marseilles, France, and showed 50\% viral clearance, as tested by RT-PCR, at Day 3 compared to $6.3 \%$ in the control group. Addition of azithromycin in this cohort seemed to augment the viral clearance [7]. The study had major limitations because it included 26 patients on HCQ from one center and 16 patients as controls from another hospital, and 6 patients from the treatment group were lost to follow-up during the survey because of early cessation of treatment. Later on, four other observational studies reported conflicting results on viral clearance at different time-points during the disease. Mallat $\mathrm{J}$ et al. [19] reported that viral negativity was significantly lower with HCQ compared to control group, whereas studies from Chen X et al [20] and Huang $M$ et al [21] did not observe rapid viral clearance by CQ. A large multi-center cohort containing 373 patients (mainly mild to moderate COVID-19) by Huang MX et al [14] reported a significantly higher rate of viral clearance at Day 10 (91.0\% vs $57.0 \%)$ and Day 14 (96.0\% vs $80.0 \%)$ in the CQ treatment group. These authors suggested that early treatment initiation (e.g. $<3$ days or 3-7 days) contributed to shorter time to undetectable viral RNA by RT-PCR. In contrast, two recently reported RCTs on HCQ from Chen J et 
al and Tang $\mathrm{W}$ et al did not reveal a higher proportion of viral clearance in patients admitted to hospital with mainly mild to moderate COVID-19 than standard of care alone [8, 22]. Our primary meta-analysis revealed a positive effect of HCQ/CQ on viral clearance by RT-PCR testing. However, this benefit was mainly attributed to the study reported by Huang MX et al, and the odds ratio was no longer significant when this study was omitted by sensitivity analysis. More remarkablly, our meta-regression analysis did not observe the coefficient of viral clearance with dose or early administration of HCQ/CQ. Thus, along with the strong evidence gathered from the above-mentioned RCTs, we can conclude that HCQ/CQ has no beneficial effect on viral clearance in COVID-19 patients.

Mortality outcomes were addressed in 7 observational studies and 2 RCTs. The studies from Yu B et al from China [23] and Membrillo FJ et al from Spain [24] reported reduced in-hospital mortality with the use of HCQ compared to standard care, but there was non-negligible bias in these studies. The first study reported clinical efficacy of low dose $(400 \mathrm{mg} /$ day) of HCQ on critically ill patients, whereas the later study reported that high dose (800mg/day) of HCQ was associated with improved survival, which was statistically significant only among patients mild COVID-19. Both of these studies had unmatched number of patients in the treatment and control groups (48 vs 502 and 123 vs 43, respectively) as a statistical limitation. On the other hand, two observational studies from Rosenberg $E$ et al [16] and Geleris $J$ et al [15], showed significantly higher mortality in the HCQ group compared to the non-treatment group, but the treated patients were obviously more severe than those in the control group. Thus, both studies performed multi-level statistical adjustments and concluded that HCQ administration was not associated with either a greatly improved or increased risk of the mortality endpoint. In our meta-analysis, we extracted adjusted events rate from these two studies to reduce the study bias. The strong evidence from the RCT by Mahevas M et al [25] also demonstrated that HCQ treatment did not have any effect on ICU admissions or death at Day 21 after hospital admission. In combination with these RCTs and real-world observational studies, our meta-analysis did not reveal a mortality benefit with administration of HCQ/CQ. On the contrary, it seems to show that HCQ/CQ treatment may even increase mortality to some extent $(\mathrm{OR}=1.26,95 \% \mathrm{Cl} 1.06-1.51)$.

A novel finding of our meta-regression analysis was that the large heterogeneity of the findings of the pooled publications might have been due to the characteristics of study cohorts, and in particular, due to their comorbidities such as hypertension, diabetes and chronic lung disease. In the presence of higher proportion of these comorbidities, there was an increased risk of mortality $(O R>1)$ with the use of $\mathrm{HCQ} / \mathrm{CQ}$. Previous studied had clearly demonstrated that patients with cardiopulmonary comorbidities had adverse outcomes, including progression into cardiac injury and death [26-28]. The potential mechanisms were also proposed based on the observations of several molecular and pathology studies [29-31]. Despite the fact that HCQ/CQ were commonly used for rheumatoid arthritis and systemic lupus erythematosus in the general population, there has been major concern with widespread use of these medications for COVID-19 due to possible QTc prolongation and induction of life-threatening arrhythmias. There is general consensus that QTc prolongation after HCQ/CQ use may occur in a dosedependent way [11, 32-35]. Previous studies demonstrated that HCQ/CQ block the hERG potassium channels, extending ventricular repolarization and action potentials, and hence, may trigger ventricular 
tachyarrhythmias $[36,37]$. Whether patients with underlying cardiopulmonary disease or those with denovo cardiac injury have a greater predilection to cardiac toxicity and increased mortality after exposure to HCQ/CQ remains uncertain but plausible.

An observational study, based on patients with systemic lupus erythematosus receiving long-term treatment of HCQ, having blood concentrations of the drug within therapeutic range, concluded that HCQ does not prevent COVID-19 in these patients [38]. Likewise, our meta-analysis did not identify any clinic benefit of using HCQ/CQ. In addition, it did not reveal any association between clinical efficacy and HCQ/CQ dose as well as disease severity. Moreover, whether these medications were administered early during the course of disease or not had no effect on clinical efficacy. Altogether, these results suggest a lack of clinical benefit with the use of HCQ/CQ in patients with COVID-19. In any case, the results of large scale, randomized clinical trials are needed to be waited before making any definitive conclusions on this controversial topic.

\section{Conclusions}

Our meta-analysis did not reveal a clinical benefit of HCQ/CQ on in-hospital outcomes for patients with COVID-19. The use of HCQ/CQ did not result in rapid viral clearance on RT-PCR. Moreover, our results showed that HCQ/CQ treatment even increase in-hospital mortality, and higher rate of comorbidities led to a higher risk of mortality by using HCQ/CQ.

\section{Abbreviations}

HCQ

Hydroxychloroquine

CQ

chloroquine

COVID-19

coronavirus disease 2019

RT-PCR

reverse transcription-polymerase chain reaction

OR

odds ratio

$\mathrm{Cl}$

confidence interval

\section{Declarations}

Ethics approval and consent participate 
This study is an meta-analysis of publications online available. No institutional review board approval was required for this study.

\section{Consent for publication}

All authors have approved publishing this paper in Infectious Diseases of Poverty, and there are no patients involved in this study.

\section{Availability of data and materials}

Not applicable.

\section{Completing interests}

We declare that we have no conflicts of interest.

\section{Funding}

This work was supported by the National Natural Science Foundation of China (81872673), the grants from the National Key Research and Development Program of China (2017YFC1200203), and by the COVID-19 research projects of Fudan University.

\section{Authors' contributions}

QJ, FD and CX supervised the study; SA, GY and HX screened the publications; GY performed statistics; LC, SA, JX and PZ prepare the primary manuscript; FD contributed draft revision and language editing. LJ and WH provided result explanations. All authors approve the final version submitted.

\section{Acknowledgements}

We acknowledge the contributions of scientists and researchers from all over the world for reporting the results in this study.

\section{References}

1. Zhu N, Zhang D, Wang W, Li X, Yang B, Song J, Zhao X, Huang B, Shi W, Lu R et al: A Novel Coronavirus from Patients with Pneumonia in China, 2019. N Engl J Med 2020, 382(8):727-733.

2. Adhikari SP, Meng S, Wu YJ, Mao YP, Ye RX, Wang QZ, Sun C, Sylvia S, Rozelle S, Raat H et al: Epidemiology, causes, clinical manifestation and diagnosis, prevention and control of coronavirus disease (COVID-19) during the early outbreak period: a scoping review. Infect Dis Poverty 2020, 9(1):29.

3. Wu Z, McGoogan JM: Characteristics of and Important Lessons From the Coronavirus Disease 2019 (COVID-19) Outbreak in China: Summary of a Report of 72314 Cases From the Chinese Center for 
Disease Control and Prevention. JAMA 2020.

4. Yang $X, Y u$ Y, Xu J, Shu H, Xia Ja, Liu H, Wu Y, Zhang L, Yu Z, Fang M et al: Clinical course and outcomes of critically ill patients with SARS-CoV-2 pneumonia in Wuhan, China: a single-centered, retrospective, observational study. Lancet Respir Med 2020:S2213-2600(2220)30079-30075.

5. Wang M, Cao R, Zhang L, Yang X, Liu J, Xu M, Shi Z, Hu Z, Zhong W, Xiao G: Remdesivir and chloroquine effectively inhibit the recently emerged novel coronavirus (2019-nCoV) in vitro. Cell Res 2020, 30(3):269-271.

6. Yao X, Ye F, Zhang M, Cui C, Huang B, Niu P, Liu X, Zhao L, Dong E, Song C et al: In Vitro Antiviral Activity and Projection of Optimized Dosing Design of Hydroxychloroquine for the Treatment of Severe Acute Respiratory Syndrome Coronavirus 2 (SARS-CoV-2). Clin Infect Dis 2020.

7. Gautret P, Lagier JC, Parola P, Hoang VT, Meddeb L, Mailhe M, Doudier B, Courjon J, Giordanengo V, Vieira VE et al: Hydroxychloroquine and azithromycin as a treatment of COVID-19: results of an openlabel non-randomized clinical trial. Int J Antimicrob Agents 2020:105949.

8. Chen J, Liu D, Liu L, Liu P, Xu Q, Xia L, Ling Y, Huang D, Song S, Zhang D, Qian Z, Li T, Shen Y, Lu H: A pilot study of hydroxychloroquine in treatment of patients with common coronavirus disease-19 (COVID-19). JOURNAL OF ZHEJIANG UNIVERSITY 2020, doi:10.3785/j.issn.1008-9292.2020.03.03

9. Chen Z, Hu J, Zhang Z, Jiang S, Han S, Yan D, Zhuang R, Hu B, Zhang Z: Efficacy of hydroxychloroquine in patients with COVID-19: results of a randomized clinical trial. medRxiv 2020:2020.2003.2022.20040758.

10. Lenzer J: Covid-19: US gives emergency approval to hydroxychloroquine despite lack of evidence. BMJ 2020, 369:m1335.

11. Jankelson L, Karam G, Becker ML, Chinitz LA, Tsai MC: QT prolongation, torsades de pointes and sudden death with short courses of chloroquine or hydroxychloroquine as used in COVID-19: a systematic review. Heart Rhythm 2020.

12. Sapp JL, Alqarawi W, Maclntyre CJ, Tadros R, Steinberg C, Roberts JD, Laksman Z, Healey JS, Krahn AD: Guidance on Minimizing Risk of Drug-Induced Ventricular Arrhythmia During Treatment of COVID-19: A Statement from the Canadian Heart Rhythm Society. Can J Cardiol 2020.

13. Lakkireddy DR, Chung MK, Gopinathannair R, Patton KK, Gluckman TJ, Turagam M, Cheung J, Patel P, Sotomonte J, Lampert R et al: Guidance for Cardiac Electrophysiology During the Coronavirus (COVID-19) Pandemic from the Heart Rhythm Society COVID-19 Task Force; Electrophysiology Section of the American College of Cardiology; and the Electrocardiography and Arrhythmias Committee of the Council on Clinical Cardiology, American Heart Association. Heart Rhythm 2020.

14. Huang M, Li M, Xiao F, Liang J, Pang P, Tang T, Liu S, Chen B, Shu J, You Y et al: Preliminary evidence from a multicenter prospective observational study of the safety and efficacy of chloroquine for the treatment of COVID-19. medRxiv 2020:2020.2004.2026.20081059.

15. Geleris J, Sun Y, Platt J, Zucker J, Baldwin M, Hripcsak G, Labella A, Manson D, Kubin C, Barr RG et al: Observational Study of Hydroxychloroquine in Hospitalized Patients with Covid-19. N Engl J Med 2020. 
16. Rosenberg ES, Dufort EM, Udo T, Wilberschied LA, Kumar J, Tesoriero J, Weinberg P, Kirkwood J, Muse A, DeHovitz J et al: Association of Treatment With Hydroxychloroquine or Azithromycin With InHospital Mortality in Patients With COVID-19 in New York State. JAMA 2020.

17. Magagnoli J, Narendran S, Pereira F, Cummings T, Hardin JW, Sutton SS, Ambati J: Outcomes of hydroxychloroquine usage in United States veterans hospitalized with Covid-19. medRxiv 2020:2020.2004.2016.20065920.

18. Borba MGS, Val FFA, Sampaio VS, Alexandre MAA, Melo GC, Brito M, Mourao MPG, Brito-Sousa JD, Baia-da-Silva D, Guerra MVF et al: Effect of High vs Low Doses of Chloroquine Diphosphate as Adjunctive Therapy for Patients Hospitalized With Severe Acute Respiratory Syndrome Coronavirus 2 (SARS-CoV-2) Infection: A Randomized Clinical Trial. JAMA Netw Open 2020, 3(4):e208857.

19. Mallat J, Hamed F, Balkis M, Mohamed MA, Mooty M, Malik A, Nusair A, Bonilla F: Hydroxychloroquine is associated with slower viral clearance in clinical COVID-19 patients with mild to moderate disease: A retrospective study. medRxiv 2020:2020.2004.2027.20082180.

20. Chen X, Zhang Y, Zhu B, Zeng J, Hong W, He X, Chen J, Zheng H, Qiu S, Deng Y et al: Associations of clinical characteristics and antiviral drugs with viral RNA clearance in patients with COVID-19 in Guangzhou, China: a retrospective cohort study. medRxiv 2020:2020.2004.2009.20058941.

21. Huang M, Tang T, Pang P, Li M, Ma R, Lu J, Shu J, You Y, Chen B, Liang J et al: Treating COVID-19 with Chloroquine. J Mol Cell Biol 2020, 12(4):322-325.

22. Tang W, Cao Z, Han M, Wang Z, Chen J, Sun W, Wu Y, Xiao W, Liu S, Chen E et al: Hydroxychloroquine in patients with mainly mild to moderate coronavirus disease 2019: open label, randomised controlled trial. BMJ 2020, 369:m1849.

23. Yu B, Li C, Chen P, Zhou N, Wang L, Li J, Jiang H, Wang DW: Low dose of hydroxychloroquine reduces fatality of critically ill patients with COVID-19. Sci China Life Sci 2020.

24. Membrillo FJ, Ramírez-Olivencia G, Estébanez M, Dios BD, Herrero MD, Mata T, Borobia AM, Gutiérrez C, Simón M, Ochoa A et al: Early Hydroxychloroquine Is Associated with an Increase of Survival in COVID-19 Patients: An Observational Study. preprint 2020.

25. Mahevas M, Tran VT, Roumier M, Chabrol A, Paule R, Guillaud C, Fois E, Lepeule R, Szwebel TA, Lescure FX et al: Clinical efficacy of hydroxychloroquine in patients with covid-19 pneumonia who require oxygen: observational comparative study using routine care data. BMJ 2020, 369:m1844.

26. Mehra MR, Desai SS, Ruschitzka F, Patel AN: Hydroxychloroquine or chloroquine with or without a macrolide for treatment of COVID-19: a multinational registry analysis. The Lancet.

27. Shi S, Qin M, Shen B, Cai Y, Liu T, Yang F, Gong W, Liu X, Liang J, Zhao Q et al: Association of Cardiac Injury With Mortality in Hospitalized Patients With COVID-19 in Wuhan, China. JAMA Cardio/ 2020.

28. Guo T, Fan Y, Chen M, Wu X, Zhang L, He T, Wang H, Wan J, Wang X, Lu Z: Cardiovascular Implications of Fatal Outcomes of Patients With Coronavirus Disease 2019 (COVID-19). JAMA Cardiol 2020.

29. Shi S, Qin M, Cai Y, Liu T, Shen B, Yang F, Cao S, Liu X, Xiang Y, Zhao Q et al: Characteristics and clinical significance of myocardial injury in patients with severe coronavirus disease 2019. Eur Heart 
$J 2020$.

30. Chen L, Li X, Chen M, Feng Y, Xiong C: The ACE2 expression in human heart indicates new potential mechanism of heart injury among patients infected with SARS-CoV-2. Cardiovasc Res 2020.

31. Varga Z, Flammer AJ, Steiger P, Haberecker M, Andermatt R, Zinkernagel AS, Mehra MR, Schuepbach RA, Ruschitzka F, Moch H: Endothelial cell infection and endotheliitis in COVID-19. Lancet 2020.

32. Nicin L, Abplanalp WT, Mellentin H, Kattih B, Tombor L, John D, Schmitto JD, Heineke J, Emrich F, Arsalan $\mathrm{M}$ et al: Cell type-specific expression of the putative SARS-CoV-2 receptor ACE2 in human hearts. Eur Heart J 2020.

33. Bessiere F, Roccia H, Deliniere A, Charriere R, Chevalier P, Argaud L, Cour M: Assessment of QT Intervals in a Case Series of Patients With Coronavirus Disease 2019 (COVID-19) Infection Treated With Hydroxychloroquine Alone or in Combination With Azithromycin in an Intensive Care Unit. JAMA Cardiol 2020.

34. Chorin E, Dai M, Shulman E, Wadhwani L, Bar-Cohen R, Barbhaiya C, Aizer A, Holmes D, Bernstein S, Spinelli $\mathrm{M}$ et al: The QT interval in patients with COVID-19 treated with hydroxychloroquine and azithromycin. Nature Medicine 2020.

35. Chorin E, Wadhwani L, Magnani S, Dai M, Shulman E, Nadeau-Routhier C, Knotts R, Bar-Cohen R, Kogan E, Barbhaiya C et al: QT Interval Prolongation and Torsade De Pointes in Patients with COVID19 treated with Hydroxychloroquine/Azithromycin. Heart Rhythm 2020.

36. Saleh M, Gabriels J, Chang D, Kim BS, Mansoor A, Mahmood E, Makker P, Ismail H, Goldner B, Willner $\mathrm{J}$ et al: The Effect of Chloroquine, Hydroxychloroquine and Azithromycin on the Corrected QT Interval in Patients with SARS-CoV-2 Infection. Circ Arrhythm Electrophysiol 2020.

37. Traebert M, Dumotier B, Meister L, Hoffmann P, Dominguez-Estevez M, Suter W: Inhibition of hERG K+ currents by antimalarial drugs in stably transfected HEK293 cells. Eur J Pharmacol 2004, 484(1):4148.

38. Mbai M, Rajamani S, January CT: The anti-malarial drug halofantrine and its metabolite $\mathrm{N}$ desbutylhalofantrine block HERG potassium channels. Cardiovasc Res 2002, 55(4):799-805.

39. Mathian A, Mahevas M, Rohmer J, Roumier M, Cohen-Aubart F, Amador-Borrero B, Barrelet A, Chauvet C, Chazal T, Delahousse M et al: Clinical course of coronavirus disease 2019 (COVID-19) in a series of 17 patients with systemic lupus erythematosus under long-term treatment with hydroxychloroquine. Ann Rheum Dis 2020, 79(6):837-839.

\section{Tables}

Table 1. Summary of characteristics of the studies included in the meta-analysis. 


\begin{tabular}{|c|c|c|c|c|c|c|c|c|c|c|}
\hline \multirow[t]{2}{*}{ ir } & \multirow[t]{2}{*}{ Country } & \multirow[t]{2}{*}{ Study Design } & \multirow{2}{*}{$\begin{array}{l}\text { Sample } \\
\text { Size }\end{array}$} & \multirow{2}{*}{ Age } & \multirow[t]{2}{*}{ Severity } & \multirow[t]{2}{*}{ Case } & \multirow[t]{2}{*}{ Control } & \multicolumn{2}{|l|}{ Outcome } & \multirow[t]{2}{*}{ Result } \\
\hline & & & & & & & & Clinical outcome & Viral clearance & \\
\hline is J & USA & Retrospective study & 1085 & 63.64 & $\begin{array}{l}\text { Mild/ } \\
\text { moderate/ } \\
\text { severe }\end{array}$ & 811 & 274 & $\begin{array}{l}\text { Intubation or } \\
\text { death }\end{array}$ & $\mathrm{NM}$ & $\begin{array}{l}\text { HCQ had no use on clinical } \\
\text { outcome }\end{array}$ \\
\hline gnoli & USA & Retrospective study & 368 & 68.96 & $\begin{array}{l}\text { Mild/ } \\
\text { moderate/ } \\
\text { severe }\end{array}$ & 210 & 158 & $\begin{array}{l}\text { Death or } \\
\text { mechanical } \\
\text { ventilation }\end{array}$ & NM & $\begin{array}{l}\text { HCQ was associated with } \\
\text { higher mortality }\end{array}$ \\
\hline \multirow[t]{2}{*}{ et $\mathrm{P}$} & France & $\begin{array}{l}\text { Open-label non- } \\
\text { randomized trial }\end{array}$ & 42 & 45.1 & $\begin{array}{l}\text { Mild/ } \\
\text { moderate/ } \\
\text { severe }\end{array}$ & 26 & 16 & $\begin{array}{l}\text { Death or transfer } \\
\text { to ICU }\end{array}$ & $\begin{array}{l}\text { viral clearance } \\
\text { at day } 6\end{array}$ & $\begin{array}{l}\text { HCQ was associated with viral } \\
\text { load reduction }\end{array}$ \\
\hline & China & Retrospective study & 550 & 68 & Severe & 48 & 502 & Death & $\mathrm{NM}$ & $\begin{array}{l}\text { HCQ decreased mortality in } \\
\text { critically ill patients }\end{array}$ \\
\hline $\mathrm{t} \mathrm{J}$ & $\begin{array}{l}\text { Abu } \\
\text { Dhabi }\end{array}$ & Retrospective study & 34 & 37 & $\begin{array}{l}\text { Mild/ } \\
\text { moderate }\end{array}$ & 21 & 13 & $\mathrm{NM}$ & $\begin{array}{l}\text { viral clearance } \\
\text { at day } 14\end{array}$ & $\begin{array}{l}\text { HCQ was associated with a } \\
\text { slower viral clearance }\end{array}$ \\
\hline $\mathrm{g} \mathrm{MX}$ & China & Prospective study & 373 & 44.6 & $\begin{array}{l}\text { Mild/ } \\
\text { moderate/ } \\
\text { severe }\end{array}$ & 197 & 176 & $\mathrm{NM}$ & \begin{tabular}{|l|} 
viral clearance \\
at day 10
\end{tabular} & $\begin{array}{l}\text { CQ associated with viral load } \\
\text { reduction }\end{array}$ \\
\hline $\bar{Z}$ & China & Retrospective study & 50 & 48.5 & $\begin{array}{l}\text { Mild/ } \\
\text { moderate }\end{array}$ & 25 & 25 & Severe pneumonia & NM & $\begin{array}{l}\text { CQ had no use on clinical } \\
\text { deterioration }\end{array}$ \\
\hline $\bar{X}$ & China & Retrospective study & 280 & - & $\begin{array}{l}\text { Mild/ } \\
\text { moderate/ } \\
\text { severe }\end{array}$ & 22 & 258 & $\mathrm{NM}$ & \begin{tabular}{|l|} 
viral clearance \\
at day 14
\end{tabular} & $\begin{array}{l}\text { CQ had no use on viral } \\
\text { clearance }\end{array}$ \\
\hline Jrillo & Spain & Retrospective study & 166 & 63.37 & $\begin{array}{l}\text { Mild/ } \\
\text { moderate/ } \\
\text { severe }\end{array}$ & 43 & 123 & Death & & HCQ improved survival \\
\hline g M & China & $\begin{array}{l}\text { Randomized } \\
\text { controlled trial }\end{array}$ & 22 & 44 & $\begin{array}{l}\text { Severe/ } \\
\text { moderate }\end{array}$ & 10 & 12 & NM & $\begin{array}{l}\text { viral clearance } \\
\text { at day } 14\end{array}$ & CQ improved viral clearance \\
\hline$\overline{\mathrm{J}}$ & China & $\begin{array}{l}\text { Randomized } \\
\text { Controlled Trial }\end{array}$ & 30 & 48.6 & $\begin{array}{l}\text { Mild/ } \\
\text { moderate }\end{array}$ & 15 & 15 & $\begin{array}{l}\text { Death and } \\
\text { deterioration }\end{array}$ & $\begin{array}{l}\text { viral clearance } \\
\text { at day } 7\end{array}$ & $\begin{array}{l}\text { HCQ had no use on viral } \\
\text { clearance }\end{array}$ \\
\hline aberg & USA & Retrospective study & 1438 & 62 & $\begin{array}{l}\text { Mild/ } \\
\text { moderate/ } \\
\text { severe }\end{array}$ & 1006 & 432 & Death & $\mathrm{NM}$ & HCQ had no use on survival \\
\hline vas & France & Retrospective study & 173 & 60 & severe & 84 & 89 & $\begin{array}{l}\text { Death or transfer } \\
\text { to ICU }\end{array}$ & NM & $\begin{array}{l}\text { HCQ had no use on survival } \\
\text { and clinical deterioration }\end{array}$ \\
\hline $\bar{W}$ & China & $\begin{array}{l}\text { Randomized } \\
\text { Controlled Trial }\end{array}$ & 150 & 46.1 & $\begin{array}{l}\text { Mild/ } \\
\text { moderate/ } \\
\text { severe }\end{array}$ & 75 & 75 & $\mathrm{NM}$ & $\begin{array}{l}\text { viral clearance } \\
\text { at day } 28\end{array}$ & $\begin{array}{l}\text { HCQ had no use on viral } \\
\text { clearance }\end{array}$ \\
\hline
\end{tabular}

HCQ, hydroxychloroquine; CQ: chloroquine

Table 2. Summary of QT prolongation and ventricular arrhythmias in patients with hydroxychloroquine or chloroquine 


\begin{tabular}{|c|c|c|c|c|c|c|}
\hline Author & Country & Study Design & $\begin{array}{l}\text { CQ/HCQ } \\
\text { Sample } \\
\text { Size } \\
\end{array}$ & CQ/HCQ dose & QT prolongation & $\begin{array}{l}\text { Ventricular } \\
\text { arrhythmias }\end{array}$ \\
\hline Molina JM & France & Prospective study & 11 & HCQ: $600 \mathrm{mg} / \mathrm{d}$ for 10 days & $1(9.1 \%)$ had $\Delta \mathrm{QTc}>60 \mathrm{~ms}$ & 0 \\
\hline Borba MGS & Brazil & $\begin{array}{l}\text { Double-masked, } \\
\text { randomized, phase } \\
\text { IIb } \\
\text { Clinical trial }\end{array}$ & 81 & \begin{tabular}{|l|} 
CQ: \\
High-dosage group:600 mg \\
BID \\
low-dosage group:450 mg \\
QD on Day 2-5
\end{tabular} & $\begin{array}{l}\text { QTc>500ms: } \\
\text { High dosage group:7 (18.9\%) } \\
\text { Low dosage group: } 4(11.1 \%)\end{array}$ & $\begin{array}{l}\text { Ventricular } \\
\text { arrhythmias: } \\
\text { High dosage: } 2 / 37 \\
(2.7 \%) \\
\text { Low dosage: } 0\end{array}$ \\
\hline Bessiere F & France & $\begin{array}{l}\text { Retrospective } \\
\text { study }\end{array}$ & 40 & $\begin{array}{l}\text { HCQ: } 200 \mathrm{mg} \text { BID for } 10 \\
\text { days }\end{array}$ & $\begin{array}{l}14(35.0 \%) \text { prolonged QTc (including } 10 \\
\text { with } \Delta \text { QTc }>60 \mathrm{~ms} \text { and } 7 \text { with QTc } \geq 500 \\
\text { ms) }\end{array}$ & 0 \\
\hline Broek & Netherland & $\begin{array}{l}\text { Retrospective } \\
\text { study }\end{array}$ & 95 & $\begin{array}{l}\text { HCQ: } 600 \mathrm{mg} \text { QD on Day } 1 \\
\text { and } 300 \mathrm{mg} \text { BID on Day2-5 }\end{array}$ & $22(23.2 \%)$ QTc $\geq 500 \mathrm{~ms}$ & 0 \\
\hline Chorin, E & USA & $\begin{array}{l}\text { Retrospective } \\
\text { study }\end{array}$ & 84 & $\begin{array}{l}\text { HCQ: } 400 \mathrm{mg} \text { BID on Day } \\
\text { and } 200 \mathrm{mg} \text { BID on Day } 2-5\end{array}$ & $9(10.7 \%)$ QTc >500 ms & 0 \\
\hline $\begin{array}{l}\text { Mercuro } \\
\text { NJ }\end{array}$ & USA & $\begin{array}{l}\text { Retrospective } \\
\text { study }\end{array}$ & 90 & $\begin{array}{l}\text { HCQ: } 400 \text { mg BID on Day 1, } \\
400 \text { mg QD on day2-5 }\end{array}$ & $\begin{array}{l}10(11.1 \%) \Delta \mathrm{QTc} \geq 60 \mathrm{~ms} \\
18(20.0 \%) \text { QTc }>500 \mathrm{~ms}\end{array}$ & $\begin{array}{l}1(1.1 \%) \text { Tdp then } \\
\text { ventricular } \\
\text { arrhythmias }\end{array}$ \\
\hline Chorin E & Italy & $\begin{array}{l}\text { Retrospective } \\
\text { study }\end{array}$ & 251 & $\begin{array}{l}\text { HCQ: } 400 \mathrm{mg} \text { BID on Day } 1 \\
\text { and } 200 \mathrm{mg} \text { BID on Day 2-5 }\end{array}$ & $\begin{array}{l}40(15.9 \%) \text { extreme QTc prolongation } \\
51(20.3 \%) \Delta \mathrm{QTc}>60 \mathrm{~ms}\end{array}$ & $1(0.4 \%) \mathrm{Tdp}$ \\
\hline Mahevas M & France & $\begin{array}{l}\text { Retrospective } \\
\text { study }\end{array}$ & 84 & HCQ: $600 \mathrm{mg} / \mathrm{d}$ & $\begin{array}{l}8 \text { (9.5\%) QTc prolongation } \\
\text { Including } 7(8.3 \%) \Delta \text { QTc }>60 \mathrm{~ms} \text { and } 1 \\
(1.2 \%) \text { QT }>500 \mathrm{~ms}\end{array}$ & 0 \\
\hline \begin{tabular}{|l|} 
Rosenberg \\
E \\
\end{tabular} & USA & $\begin{array}{l}\text { Retrospective } \\
\text { study }\end{array}$ & 1006 & HCQ: $200-600 \mathrm{mg} / \mathrm{d}$ & 119 (13.7\%) QTc prolongation & $\begin{array}{l}151(9.1 \%) \text { cardiac } \\
\text { arrest }\end{array}$ \\
\hline Saleh M & USA & Prospective study & 201 & $\begin{array}{l}\text { CQ: } 500 \mathrm{mg} \text { BID on Day } 1 \\
\text { and } 500 \mathrm{mg} \text { QD on Day 2-5, } \\
\text { HCQ: } 400 \mathrm{mg} \text { BID on Day } 1 \\
\text { and } 200 \mathrm{mg} \text { BID on Day 2-5 }\end{array}$ & $18(9.0 \%)$ QTc $>500 \mathrm{~ms}$ & $\begin{array}{l}8(4.0 \%) \text { ventricular } \\
\text { arrhythmias }\end{array}$ \\
\hline Cipriani A & Italy & Prospective study & 22 & HCQ: $200 \mathrm{mg}$ BID $\geq 3$ days & $1(4.5 \%)$ QTc $>500 \mathrm{~ms}$ & $1(4.5 \%)$ NSVT \\
\hline
\end{tabular}

HCQ,hydroxychloroquine; CQ: chloroquine; NSVT: non-sustained ventricular tachycardia

Figures 


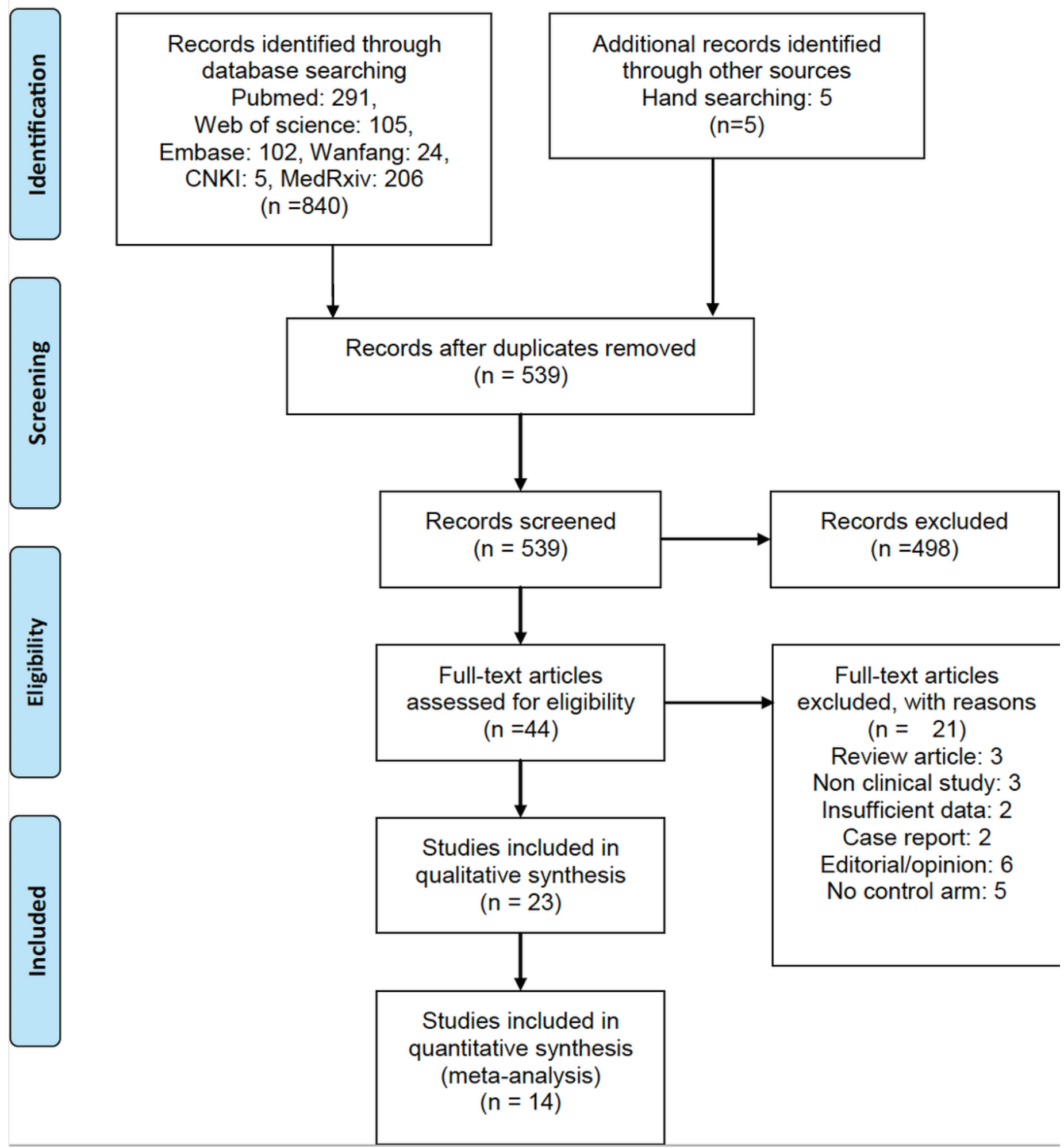

Figure 1

Flowchart of the article selection process 


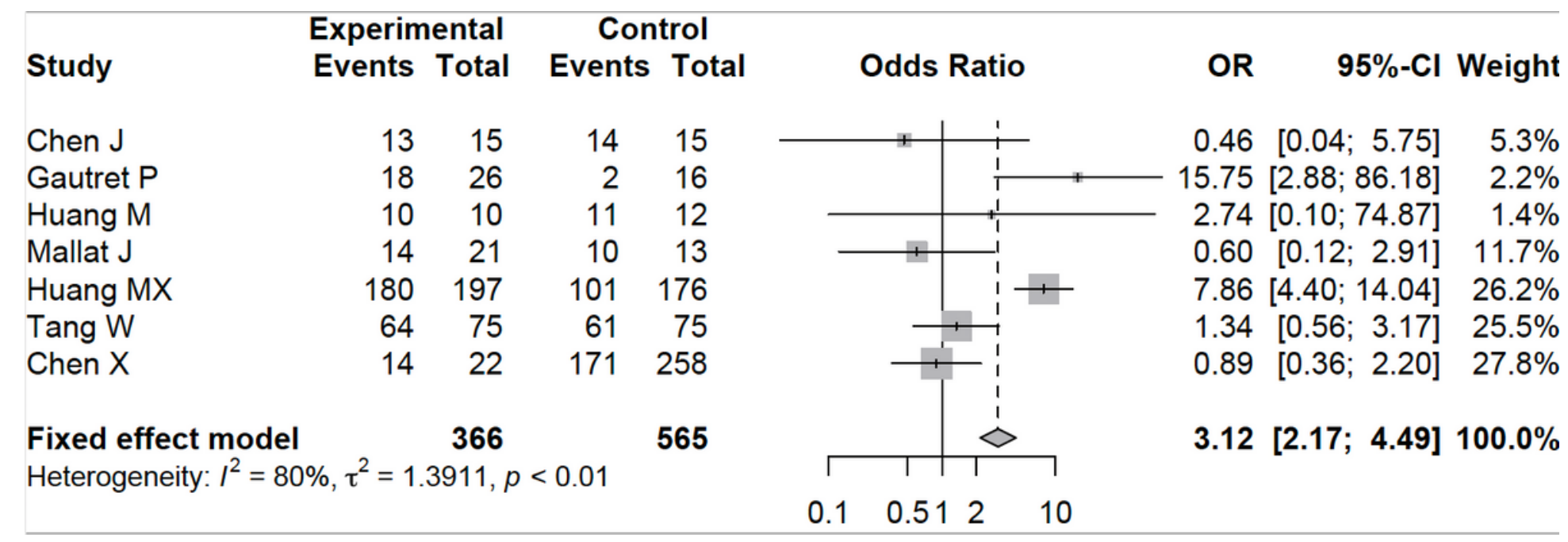

Figure 2

Forest map by meta-analysis of the clinical efficacy of hydroxychloroquine or chloroquine on viral clearance in patients with COVID-19. Cl: confidence interval; OR: odds ratio 
OR $\quad 95 \%-\mathrm{Cl}$

Omitting Chen J

Omitting Gautret $P$

Omitting Huang $M$

Omitting Mallat J

Omitting Huang $M X$

Omitting Tang W

Omitting Chen $X$

Fixed effect model

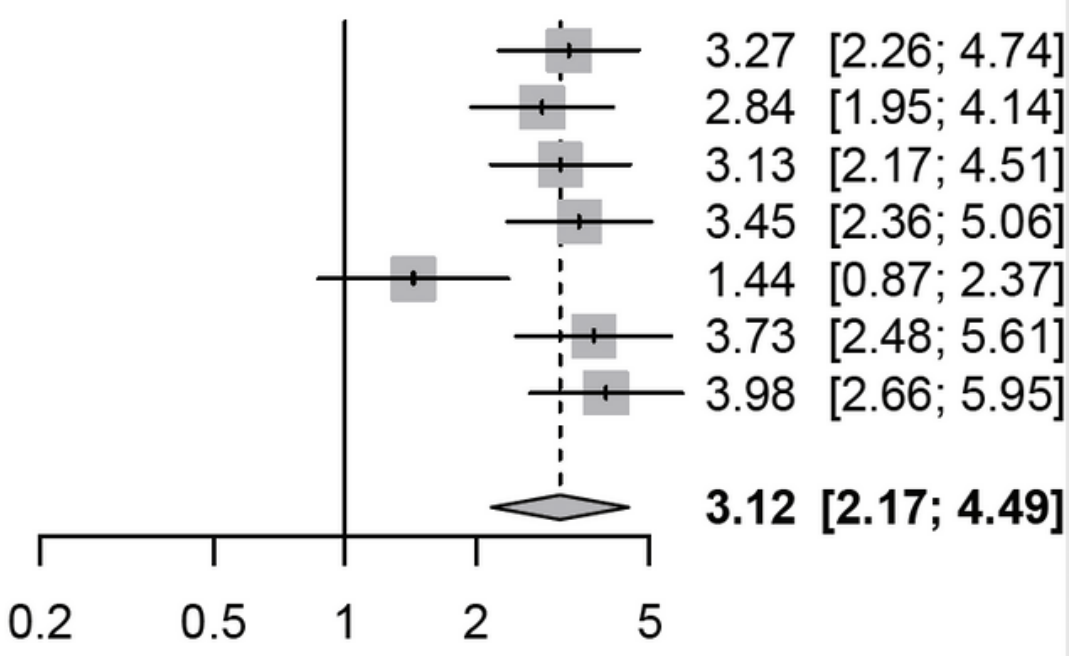

B

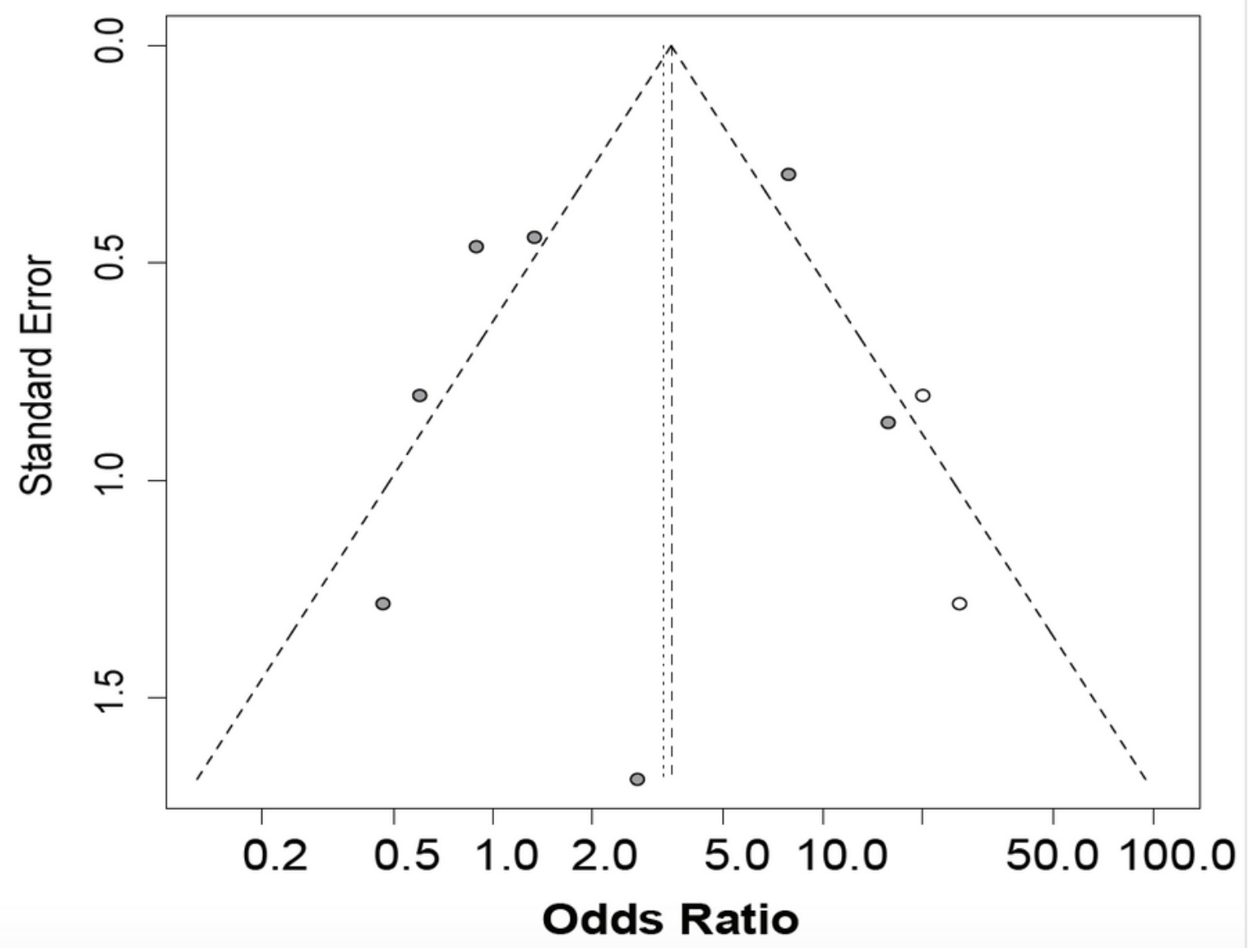

Figure 3

(A) Sensitivity analysis. (B) Adjusted Egger's plots analyses for the potential publication bias among the studies about viral clearance outcomes. Cl: confidence interval; OR: odds ratio 


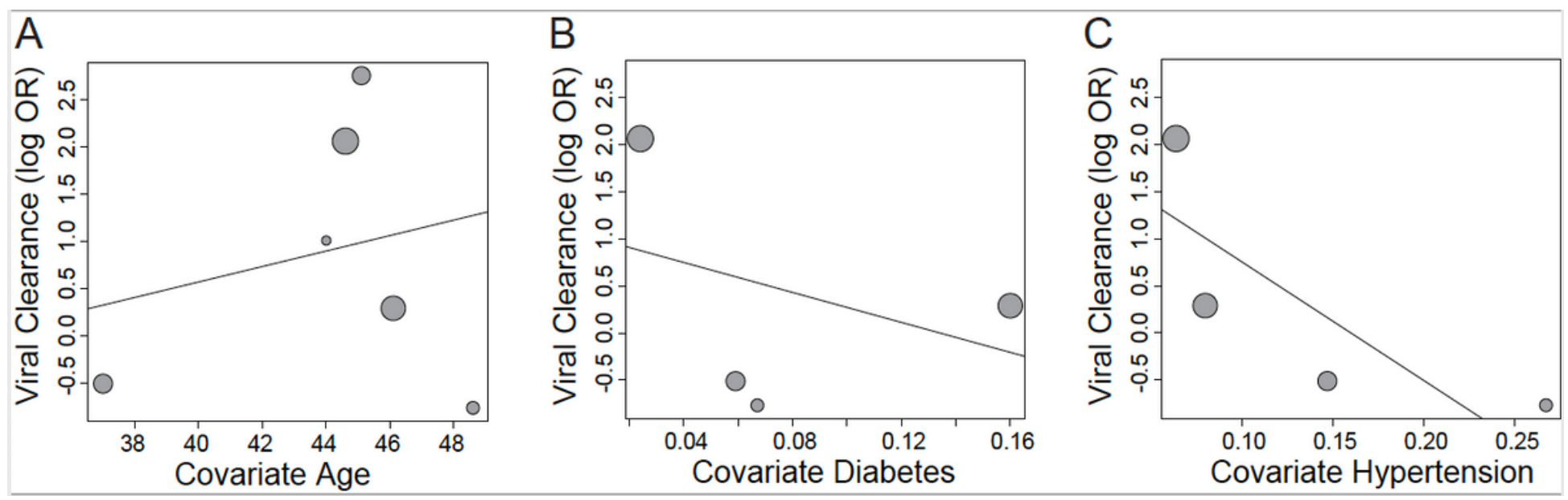

Figure 4

The associations of viral clearance rate and age $(p=0.649)$, proportions $(p=0.604)$ of diabetes, and proportions of hypertension $(p=0.145)$ of study cohorts by meta-regression analysis.

\begin{tabular}{|c|c|c|c|c|c|c|c|}
\hline Study & $\begin{array}{l}\text { Experim } \\
\text { Events }\end{array}$ & $\begin{array}{r}\text { iental } \\
\text { Total }\end{array}$ & $\begin{array}{r}\text { Co } \\
\text { Event }\end{array}$ & $\begin{array}{l}\text { ntrol } \\
\text { Total }\end{array}$ & \multicolumn{3}{|c|}{ Odds Ratio } \\
\hline Yu B & 9 & 48 & 238 & 502 & \multirow[t]{2}{*}{ 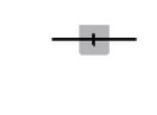 } & \\
\hline Chen J & 0 & 15 & 0 & 15 & & $i$ & \\
\hline Gautret P & 1 & 26 & 0 & 16 & \multirow[b]{4}{*}{ 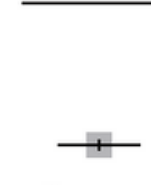 } & $a_{1}^{1}$ & \\
\hline Magagnoli J & 52 & 210 & 18 & 158 & & \multirow{2}{*}{\multicolumn{2}{|c|}{$\div$}} \\
\hline Geleris J & 262 & 811 & 66 & 274 & & & \\
\hline Membrillo FJ & 27 & 123 & 21 & 43 & & \\
\hline Feng Z & 0 & 25 & 3 & 25 & & \multicolumn{2}{|l|}{$\frac{1}{1}$} \\
\hline Mahevas M & 9 & 84 & 8 & 89 & & \multicolumn{2}{|l|}{1} \\
\hline Rosenberg E & 216 & 1006 & 62 & 432 & & \multicolumn{2}{|l|}{$\frac{1}{1+}$} \\
\hline Fixed effect model & & 2348 & & 1554 & & \multicolumn{2}{|l|}{ is } \\
\hline \multirow{2}{*}{ Heterogeneity: $I^{2}=84 \%$} & \multirow{2}{*}{$t^{2}=0.4$} & $4784, p$ & $<0.01$ & & 1 & 千 & 1 \\
\hline & & & & & 0.1 & 1 & 10 \\
\hline
\end{tabular}

OR $\quad 95 \%-\mathrm{Cl}$ Weight

$0.26[0.12 ; 0.54] \quad 15.4 \%$

$1.94[0.07 ; 50.56] \quad 0.3 \%$

$2.56[1.43 ; 4.58] \quad 7.0 \%$

$1.50[1.10 ; 2.06] \quad 30.4 \%$

$0.29[0.14 ; 0.61] 11.1 \%$

$0.13[0.01 ; 2.58] \quad 1.6 \%$

$1.22[0.45 ; 3.31] \quad 3.2 \%$

$1.63[1.20 ; 2.22] \quad 31.1 \%$

$1.26[1.06 ; 1.51] 100.0 \%$

Figure 5

Forest map by meta-analysis of the clinical efficacy of hydroxychloroquine or chloroquine on in-hospital mortality in patients with COVID-19. Cl: confidence interval; OR: odds ratio 
A

Study

Omitting Yu B

Omitting Chen J

Omitting Gautret $P$

Omitting Magagnoli J

Omitting Geleris J

Omitting Membrillo FJ

Omitting Feng $Z$

Omitting Mahevas $M$

Omitting Rosenberg $\mathrm{E}$

Fixed effect model
Odds Ratio

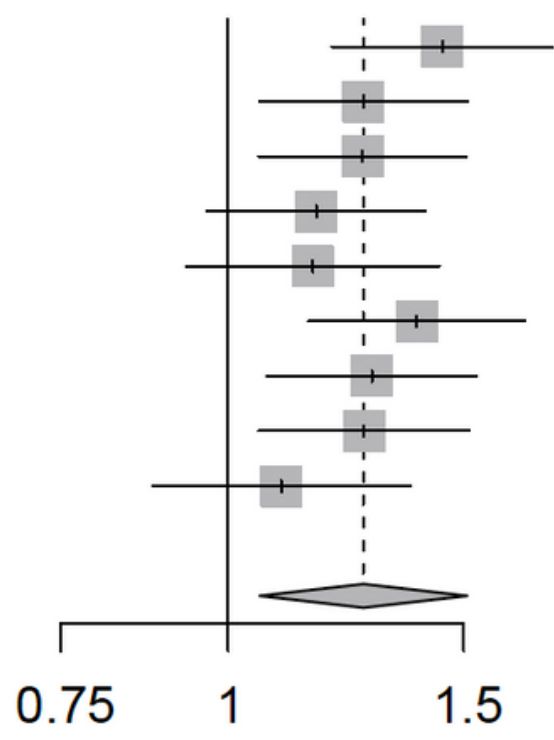

OR $\quad 95 \%-\mathrm{Cl}$

$1.45[1.20 ; 1.75]$

$1.26[1.06 ; 1.51]$

$1.26[1.05 ; 1.51]$

$1.16[0.96 ; 1.41]$

$1.16[0.93 ; 1.44]$

$1.38[1.15 ; 1.67]$

1.28 [1.07; 1.53]

$1.26[1.05 ; 1.52]$

$1.10[0.88 ; 1.37]$

$1.26[1.06 ; 1.51]$

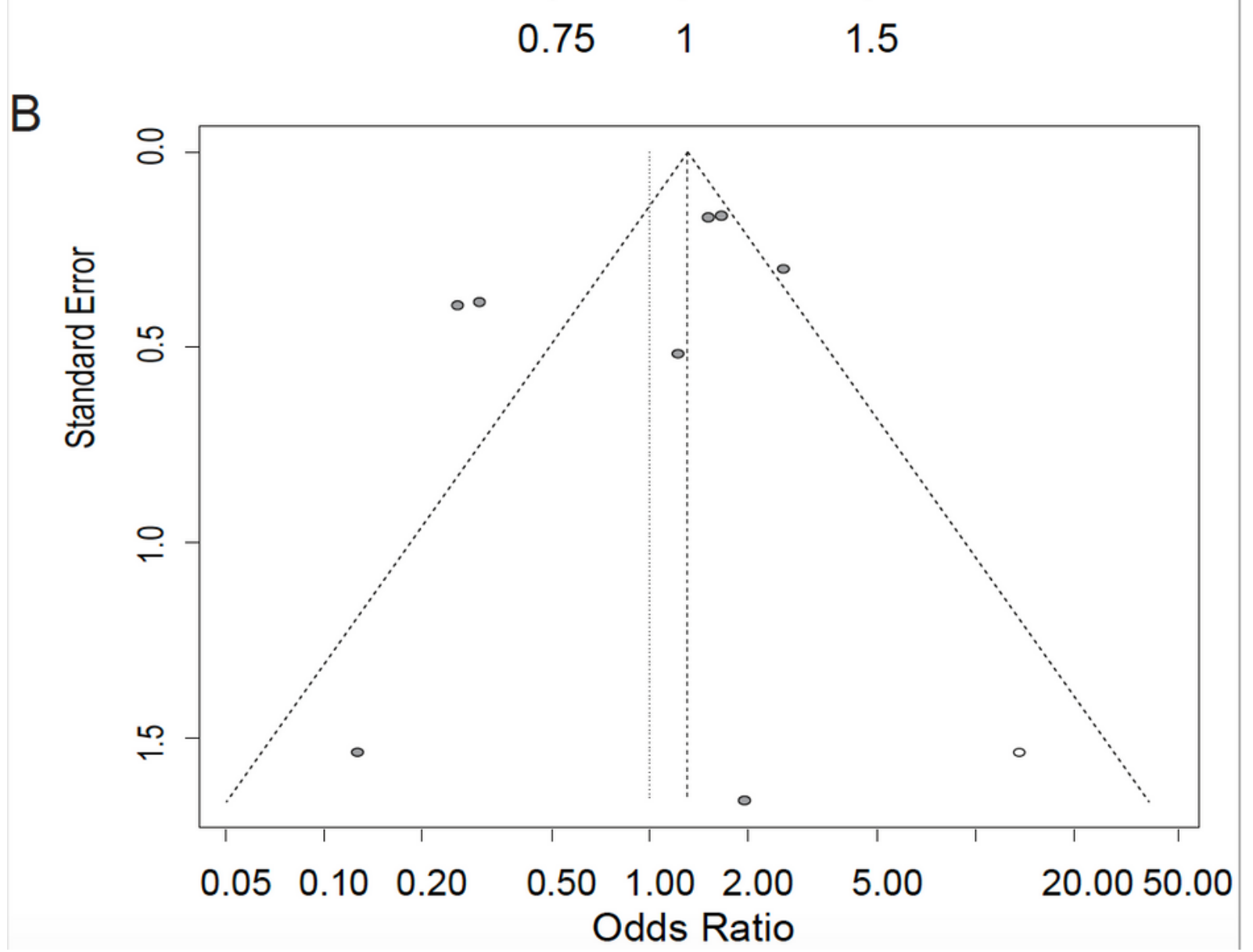

Figure 6

(A) Sensitivity analysis. (B) Adjusted Egger'splots analyses for the potential publication bias among the studies about mortality outcome. Cl: confidence interval; OR: odds ratio 

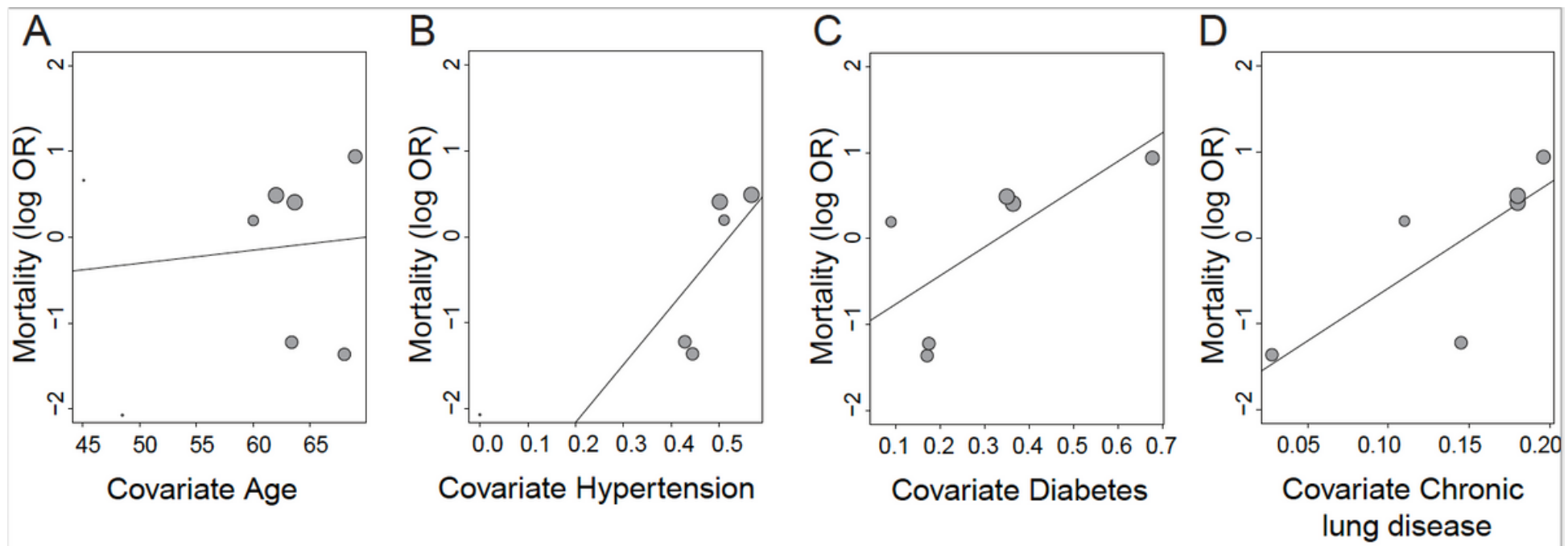

Figure 7

The associations of in-hospital mortality and age $(A, p=0.617)$, proportions of hypertension $(B, p=0.025)$, proportions of diabetes $(C, p=0.049)$ and proportions of chronic lung disease $(D, p=0.006)$ of study cohorts by meta-regression analysis. 